\title{
Application for Hybrid Rice Technology at Egypt
}

\author{
Mahmoud Abo-Yousef \\ Head of research \\ Rice Research department- FCRI- ARC \\ Corresponding author: abo_yousef709@yahoo.com
}

\begin{abstract}
Commercial exploitation of hybrid vigor is one of the most important applications of genetics in agriculture. It has not only contributed to food security, but has also benefited the environment, the hybrid rice Produced by crossing between two parents and the productivity increased by 20-30\% than the inbred high yielding variety. The systematic of hybrid rice included three line system, two line system and One line system. The PCR technique can be used as one of the indicator for predicting the genetic purity of CMS lines, based on polymorphism among parental lines, this characteristic has been used in China to perform preliminary evaluation of the purity of hybrid rice seeds. Hybrid rice research was initiated in Egypt in 1982, to determine natural fertility restoration of Egyptian varieties on some Chinese CMS lines, evaluate certain CMS lines, test productivity of some hybrid varieties and to estimate yield and determination of seed setting percentage of some CMS lines under Egyptian conditions, but, the first Egyptian hybrid was released during 2004. For the two line system, discovery and successful utilization of environmental genic male sterility (EGMS) led to development new promising hybrids of the two lines system in hybrid rice breeding program, compared with the three-line system. EGMS trait is governed by major genes could be transferred to any genetic background and no need to use restorer genes in the male parents of two line hybrids. Finally, this system is ideal for developing indica / japonica hybrids because most japonica lines do not possess restorer genes. Molecular studies is concerning on selecting populations which can be used as the new reverse-thermo sensitive genic male sterile (rTGMS) lines to produce Japonica hybrids under Egyptian condition by using one specific SSR primer RM222.
\end{abstract}

Keywords: Hybrid, Rice, Technology, PCR

\section{Introduction}

Rice (Oryza Sativa L.) is considered as one of the most important cereal crops, not only in Egypt, but also, all over the world and cultivated in around 113 countries of the world. About half of the world's population depends on rice for their survival, commercial exploitation of hybrid vigor is one of the most important applications of genetics in agriculture. It has not only contributed to food security, but has also benefited the environment, the hybrid rice Produced by crossing between two parents and the productivity increased by $20-30 \%$ than the inbred high yielding variety. The systematic of hybrid rice included three line system, two line system and One line system. For three line system. Hybrid rice based on cytoplasmic male sterility (CMS) increases grain yield by more than $20 \%$ relative to improved inbred rice varieties, if the seed purity is less than 90 percent, hybrid rice will not have any advantage over conventional rice. If there is no high seed purity, there would be no high yield of hybrid rice Yuan $\boldsymbol{e t}$ al (2003). The PCR technique can be used as one of the indicator for predicting the genetic purity of CMS lines, based on polymorphism among parental lines, this characteristic has been used in China to perform preliminary evaluation of the purity of hybrid rice seeds. Hybrid rice research was initiated in Egypt in 1982, to determine natural fertility restoration of Egyptian varieties on some Chinese CMS lines, evaluate certain CMS lines, test productivity of some hybrid varieties and to estimate yield and determination of seed setting percentage of some CMS lines under Egyptian conditions (Maximose and Aidy, 1994), but, the first Egyptian hybrid was released during 2004, Bastawisi et al (2005).

For the two line system, discovery and successful utilization of environmental genic male sterility (EGMS) led to development new promising hybrids of the two lines system in hybrid rice breeding program, compared with the three-line system. The two line system has many advantages for hybrid rice production such as no need to use maintainer line for seed parent multiplication, thus making seed production simpler and more cost-effective. EGMS trait is governed by major genes could be transferred to any genetic background and no need to use restorer genes in the male parents of two line hybrids. Finally, this system is ideal for developing indica / japonica hybrids because most japonica lines do not possess restorer genes. Molecular studies is concerning on selecting populations which can be used as the new reverse-thermo sensitive genic male sterile (rTGMS) lines to produce Japonica hybrids under Egyptian condition by using one specific SSR primer RM222.

\section{Advantage of hybrid rice technology:}

1- The success of hybrid rice planting depends on the success of hybrid rice breeding and seed production program, which enables seed producers to produce high quality of seeds at an economical price.

2- Improvement of breeding and seed production technology led to increase of grain yield as a result 
of using high pure seeds, which might decrease the cost of hybrid rice.

3- The seeds of A lines with, 100 percentage of purity are required to achieve the maximum grain yield of hybrid rice under biotic and abiotic stress.

The systems of hybrid rice for exploitation of heterosis:

1- Three line method or CMS system.

2- Two line method or PTGMS system.

3- One line method or system (Apomixis system ) is the ability of ovule to produce seeds without pollination, to transfer apomixis into crop plants egg cell is the cell that has ability to produce apomixis not any other cell in ovary tissue. Yuan et al (2003)

Also could be exploitation of heterosis could be through:

1- Intervarietal hybrids

2- Intersubspecific hybrids

3- Interspecific or intergeneric hybrids (distance hybrids).

\section{Frist system: Concept of three lines and their} interrelation.

4- CMS line: The CMS line refers to a special kind of breeding line whose anthers are abnormal, no pollen or only abortive pollen exists within the CMS line anthers, so no seed is set on these lines by selfing. However, pistils of the $\mathrm{cms}$ line are normal and can produce seeds when pollinated by normal rice.

5- Maintainer line: The maintainer line is a specific pollination of the corresponding CMS line and thereby producing progenies that still retain male sterility. If there is no maintainer line the CMS line cannot be maintained and multiplied from generation to generation.

6- Restorer line: The restorer line is a pollinator variety used for pollinating the CMS line to produce $\mathrm{F} 1$ hybrids that become normal in fertility and thus can produce seeds by selfing.

1- Interrelations among the three lines

(A, B and $\mathrm{R}$ line) For hybrid rice seed production

Step 1 A X B Multiplication of female (CMS ) line

Step 2 A X R F1 hybrid seed production

F1 hybrid seed For commercial cultivation

\section{Procedures of hybrid rice breeding.}

\section{1-Source, testcross and re-testcross nursery.}

Development and identification of high yielding hybrids is one of the major objectives of these technology as well as, restorer lines and maintainer lines, El-Mowafi et al (2005). In a study conducted at RRTC during 2015 and 2016 seasons by Abo yousef et al (2017), included three CMS lines with six tester lines, the results showed that, there were significant differences among the lines for all the measured traits, the line K17A recorded the desirable values for days to $50 \%$ heading, plant height and 1000 grain weight, while the lines IR69625A and G46A recorded the highest values for seed set $\%$, grain yield and harvest index $\%$. Most of the yield characters recorded on the sister line (B- line), the mean performance of the parents and their F1 crosses for morphological and yield traits are presented in Table 1. For testers, the Giza 179 recorded the desirable values with days to $50 \%$ heading, plant height, 1000 grain weight and grain yield per plant, while, the Giza 178Mutant 4 and Giza 178Mutant1 recorded desirable values for seed set $\%$ and harvest index $\%$, respectively, these results were similar to those of Katta et al (2015). Among the hybrid combinations, K17A x Giza 179 and G46A x Giza 179 showed the desirable values for days to $50 \%$ heading and the hybrid combination IR69625A x GZ 9363 showed the shortest stature. Concerning of 1000grain weight, the hybrids K17A x GZ9363 and IR69625A x Giza 178M1 showed the highest values. Finally, with regard to seed set $\%$ and grain yield, the hybrids IR69625A x Giza 178Mutant3; IR69625A x Giza 178M4 and G46A x Giza 178M3 showed the highest values for seed set $(\%)$ and grain yield per plant, respectively), these results may be referred to stability of favorable weather conditions and homogeneity to soil fertility and suggested that, these hybrids could be released as promising hybrids in hybrid rice program.

Heterosis: That means (superiority) increase or decrease of the $F_{1}$ performance compared to their parents in all plant characters under biotic and a biotic stress conditions. In this study, the heterosis $\%$ for botanical and yield related traits were computed according to mid parent and over better parent. The magnitudes of heterosis varied from trait to trait and cross to cross. The mid parent heterosis for days to $50 \%$ heading was estimated, the crosses, IR69625A x Giza 178M4, IR69625A x Giza 179, G46A x Giza 178M4 and G46A x Giza 179 recorded significant and negative heterosis, while, for plant height none of the hybrids manifested significant negative heterosis. Regarding yield and its components, the crosses; G46A x Giza 179, G46A x Giza 178M4, K17A x Giza 179, K17A x Giza 178M3, G46A x Giza 178M1, K17A x Giza 178M4, K17A x GZ9363, K17A x Giza 178M4, G46A x Giza 178M4, IR69625A x Giza 178M4 and IR69625A x Giza 178M1 recorded significant and positive heterosis. From these results the hybrid combinations G46A x Giza 178M4, G46A x Giza 179, K17A x Giza 178M4, K17A x GZ9363, G46A x Giza 178M4 and IR69625A x Giza 178M4 could be selected as promising hybrids, because they recoded the desirable values for yield characters as shown in Table 2. For better parent heterosis the crosses; IR69625A x Giza 178M4, G46A x Giza $178 \mathrm{M} 3$ recorded significant and negative heterosis, 
but, for plant height none of the hybrids recorded significant negative heterosis, while, the crosses; G46A x Giza 179, G46A x Giza 178M4, G46A x Giza 179, K17A x Giza 178M1, G46A x Giza 178M1, IR69625A x Giza 178M3, G46A x Giza 178M3, K17A x GZ9363, IR69625A x Giza 178M4, IR69625A x Giza 178M3, IR69625A x Giza 179 recorded significant and positive heterosis for yield and its components. From these results the hybrid combinations; IR69625A x Giza 178M4, G46A x Giza 179, G46A x Giza 178M4, IR69625A x Giza 178M3, K17A x GZ9363 and K17A Giza 178M4 could be selected as promising hybrids, because they recorded the desirable values for botanical and yield characters on the base of better parent heterosis \% as shown in
Table 2. These results may be confirmed with primary hypotheses of heterosis which referred to : a) Dominance hypotheses : heterosis in F1 hybrids results from the accumulation of favorable dominant genes from both parents : b) Over dominance hypotheses : heterosis is caused by the heterogeneous combination of allelic genes in F1 hybrids and the effect of heterogeneous allelic genes is greater than that of homogeneous allelic genes, i. e. , $a_{1} a_{2}>a_{1} a_{1}$ or $a_{1} a_{2}$ : c ) Epistatic effect that referred to non-allelic interaction is a common contributor to heterosis, this model emphasizes that heterosis is a multilocus effect rather than the effect of loci acting singly, for example, when crossing $\mathrm{AABB}$ with $\mathrm{aaBB}$ and aabb, only $\mathrm{AaBB}$ shows heterosis while $\mathrm{AaBb}$ not.

Table 1. The mean performances of all genotypes for some botanical and yield characters during 2016 season.

\begin{tabular}{|c|c|c|c|c|c|c|}
\hline Genotypes & $\begin{array}{c}\text { Days to 50\% } \\
\text { heading } \\
\text { (day) }\end{array}$ & $\begin{array}{c}\text { Plant } \\
\text { height } \\
(\mathbf{c m})\end{array}$ & $\begin{array}{c}\text { Seed set } \\
\%\end{array}$ & $\begin{array}{l}1000 \text { grain } \\
\text { weight (g) }\end{array}$ & $\begin{array}{c}\text { Grain yield } \\
\text { per plant }{ }^{-1} \\
(\mathrm{~g})\end{array}$ & $\begin{array}{c}\text { Harvest } \\
\text { index }(\%)\end{array}$ \\
\hline \multicolumn{7}{|l|}{ lines } \\
\hline IR69625A (P1) & 102.333 & 96.323 & $94.930 *$ & $24.430 *$ & $40.450 *$ & $49.000 *$ \\
\hline $\mathrm{K} 17 \mathrm{~A}(\mathrm{P} 2)$ & 85.000 & 85.407 & $87.280 *$ & $26.770 *$ & $33.200 *$ & $50.423 *$ \\
\hline G46A (P3) & 99.000 & 90.990 & $95.233^{*}$ & $26.667 *$ & $35.470 *$ & $54.003 *$ \\
\hline Mean & 95.444 & 90.907 & 92.481 & 26.024 & 36.373 & 51.141 \\
\hline \multicolumn{7}{|l|}{ Tester } \\
\hline Giza178M $1(\mathrm{P} 4)$ & 102.000 & 104.203 & 96.880 & 24.067 & 39.567 & 57.267 \\
\hline Giza178M 2 (P5) & 100.333 & 106.130 & 96.533 & 24.550 & 41.667 & 56.660 \\
\hline Giza178M ${ }_{3}(\mathrm{P} 6)$ & 100.333 & 106.737 & 95.600 & 24.823 & 42.207 & 56.083 \\
\hline Giza178M 4 (P7) & 99.667 & 107.407 & 96.660 & 25.083 & 42.637 & 53.267 \\
\hline Giza 179(P8) & 90.667 & 91.100 & 95.380 & 28.167 & 44.683 & 50.930 \\
\hline GZ9363(P9) & 93.000 & 98.173 & 95.150 & 25.717 & 41.103 & 55.523 \\
\hline Mean & 97.667 & 102.292 & 96.034 & 25.401 & 41.977 & 54.955 \\
\hline \multicolumn{7}{|l|}{ Crosses } \\
\hline IR69625AxGiza178M1 & 102.667 & 103.750 & 95.387 & 24.850 & 50.367 & 66.783 \\
\hline IR69625Ax & 101.000 & 105.300 & 96.300 & 25.183 & 51.643 & 58.337 \\
\hline Giza178M2 & 101.667 & 105.627 & 97.080 & 25.497 & 58.297 & 61.743 \\
\hline IR69625Ax & 95.000 & 108.283 & 97.367 & 25.833 & 59.037 & 65.540 \\
\hline Giza178M3 & 92.333 & 102.360 & 95.823 & 26.433 & 57.467 & 57.403 \\
\hline IR69625Ax & 94.667 & 99.583 & 93.317 & 25.767 & 52.260 & 64.720 \\
\hline Giza178M4 & 98.667 & 105.333 & 87.807 & 26.333 & 51.513 & 58.190 \\
\hline IR69625Ax Giza179 & 98.333 & 103.233 & 90.117 & 25.500 & 52.227 & 59.807 \\
\hline IR69625Ax GZ9363 & 98.667 & 102.000 & 95.320 & 26.200 & 53.727 & 56.573 \\
\hline K17Ax Giza178M1 & 98.667 & 108.220 & 95.463 & 26.000 & 57.217 & 63.480 \\
\hline K17Ax Giza178M2 & 90.667 & 101.500 & 91.523 & 28.067 & 55.650 & 56.150 \\
\hline K17Ax Giza178M3 & 92.333 & 101.250 & 91.553 & 29.833 & 50.140 & 59.887 \\
\hline K17Ax Giza178M4 & 100.667 & 115.733 & 94.740 & 25.267 & 52.187 & 65.050 \\
\hline K17Ax Giza179 & 98.667 & 117.887 & 94.400 & 24.583 & 55.490 & 60.953 \\
\hline K17Ax GZ9363 & 95.667 & 105.750 & 96.967 & 23.343 & 56.467 & 63.827 \\
\hline G46Ax Giza178M1 & 98.333 & 117.167 & 94.440 & 25.400 & 57.333 & 62.960 \\
\hline G46Ax Giza178M2 & 90.333 & 112.140 & 95.563 & 27.933 & 57.440 & 53.747 \\
\hline G46Ax Giza178M3 & 94.667 & 110.167 & 89.503 & 27.837 & 52.027 & 60.660 \\
\hline \multicolumn{7}{|l|}{ G46Ax Giza178M4 } \\
\hline \multicolumn{7}{|l|}{ G46Ax Giza179 } \\
\hline \multicolumn{7}{|l|}{ G46Ax GZ9363 } \\
\hline Mean & 96.833 & 106.960 & 94.037 & 26.103 & 54.474 & 60.881 \\
\hline G. Mean & 96.864 & 104.139 & 94.308 & 25.939 & 49.686 & 58.162 \\
\hline LSD 0.05 & 1.051 & 0.885 & 0.800 & 0.539 & 0.714 & 0.802 \\
\hline 0.01 & 1.398 & 1.176 & 1.064 & 0.717 & 0.949 & 1.066 \\
\hline
\end{tabular}




\section{2- Backcross nursery :}

To develop an excellent CMS line and its corresponding maintainer line, the sterile hybrid plants and the recurrent male plants should be grown in pairs in the backcross nursery, successive backcrosses should be carried out for to six generations depending on breeders, when the backcross progenies are stable in sterility and apparently conform to the characteristics of the male parent and when the population consists of over 1000 plants these progenies are designated a CMS line, the corresponding male parent used as the recurrent parent is designated a maintainer line. The following study showed procedures to purification to CMS lines under Egyptian conditions.
The PCR technique can be used as one of the indicator for predicting the genetic purity of CMS lines, based on polymorphism among parental lines. This characteristic has been used in China to perform preliminary evaluation of the purity of hybrid rice seeds. Many scientists studied the correlation of the PCR bands with purity in female parent, on the bases of a number of bands with high activity. It was concluded that the genetic purity of hybrid seeds could differ from place to another under a large scale, depending on the synchronization of flowering for parental lines and the seed purity of the female line (CMS).

Table 2. Heterosis relative to better parent for some botanical, yield and its component characters during 2016 season.

\begin{tabular}{|c|c|c|c|c|c|c|}
\hline \multirow[b]{2}{*}{ Hybrid combination } & \multicolumn{6}{|c|}{ Traits } \\
\hline & $\begin{array}{c}\text { Days to } \\
50 \% \\
\text { heading } \\
\text { (day) }\end{array}$ & $\begin{array}{l}\text { Plant } \\
\text { height } \\
(\mathrm{cm})\end{array}$ & Seed set $(\%)$ & $\begin{array}{c}\text { 1000- } \\
\text { grain } \\
\text { weight (g) }\end{array}$ & $\begin{array}{l}\text { Grain } \\
\text { yield per } \\
\text { plant-1 } \\
(\mathrm{g})\end{array}$ & $\begin{array}{c}\text { Harvest } \\
\text { index }(\%)\end{array}$ \\
\hline IR69625Ax Giza178M & 0.654 & $7.714^{* * *}$ & $-1.54^{1 * *}$ & $1.719^{* *}$ & $24.516^{* *}$ & $16.618^{* *}$ \\
\hline IR69625Ax Giza178M & 0.668 & $9.323^{* *}$ & -0.242 & $2.580^{* *}$ & $23.934^{* *}$ & $3.030^{* *}$ \\
\hline IR69625Ax Giza178M & $1.332^{* *}$ & $9.662^{* *}$ & $1.548^{* *}$ & $2.713^{* *}$ & $38.111^{* *}$ & $10.092^{* *}$ \\
\hline IR69625Ax Giza178M & $-4.685^{* *}$ & $12.420^{* *}$ & 0.731 & $2.990^{* *}$ & $38.454^{* *}$ & $23.041^{* *}$ \\
\hline IR69625Ax Giza179 & $1.834^{* *}$ & $12.360^{* *}$ & 0.465 & $-6.154^{* *}$ & $28.618^{* * *}$ & $12.710^{* *}$ \\
\hline IR69625Ax GZ9363 & $1.792^{* *}$ & $3.388^{* *}$ & $-1.927^{* *}$ & 0.194 & $27.153^{* *}$ & $16.564^{* *}$ \\
\hline K17Ax Giza178M & $16.078^{* *}$ & $23.327^{* *}$ & $-9.366^{* *}$ & $-2.397^{* *}$ & $30.183^{* *}$ & $1.612^{* *}$ \\
\hline K17Ax Giza178M 2 & $15.686^{* * *}$ & $20.868^{* *}$ & $-6.647^{* *}$ & $-5.486^{* *}$ & $25.454^{* *}$ & $5.554^{* *}$ \\
\hline K17Ax Giza178M 3 & $16.078^{* * *}$ & $19.424^{* *}$ & -0.293 & $-2.891^{* *}$ & $27.284^{* *}$ & $0.874^{*}$ \\
\hline K17Ax Giza178M 4 & $16.078^{* * *}$ & $26.706^{* *}$ & $-1.238^{* *}$ & $-3.632^{* *}$ & $34.185^{* *}$ & $19.174^{* *}$ \\
\hline K17Ax Giza179 & $6.667^{* *}$ & $18.839^{* *}$ & $-4.043^{* *}$ & -0.367 & $24.552^{* *}$ & $10.249^{* *}$ \\
\hline K17Ax GZ9363 & $8.627^{* *}$ & $18.546^{* *}$ & $-3.780^{* *}$ & $10.576^{* *}$ & $21.995^{* *}$ & $7.859^{* *}$ \\
\hline G46Ax Giza178M & $1.684^{* *}$ & $27.193^{* *}$ & $-2.209^{* *}$ & $-5.262^{* *}$ & $31.884^{* * *}$ & $13.591^{* *}$ \\
\hline G46Ax Giza178M & -0.337 & $29.560^{* *}$ & $-2.210^{* *}$ & $-7.824^{* *}$ & $33.165^{* *}$ & $7.577^{* *}$ \\
\hline $\mathrm{G}_{46 \mathrm{Ax}}$ Giza178M 3 & $-3.367^{* *}$ & $16.222^{* *}$ & $1.430^{* * *}$ & $-12.473^{* *}$ & $33.776^{* * *}$ & $13.807^{* *}$ \\
\hline $\mathrm{G}_{46 \mathrm{Ax}}$ Giza178M & -0.673 & $28.769^{* *}$ & $-2.297^{*}$ & $-4.762^{* *}$ & $34.459^{* * *}$ & $16.585^{* *}$ \\
\hline G46Ax Giza179 & -0.371 & $23.244^{* *}$ & 0.192 & $-0.840^{* *}$ & $28.559^{* *}$ & -0.475 \\
\hline G46Ax GZ9363 & $1.792^{* *}$ & $21.076^{* *}$ & $-6.017^{* *}$ & $4.374^{* *}$ & $26.586^{* *}$ & $9.251^{* *}$ \\
\hline
\end{tabular}

* and ** Significant at 0.05 and 0.01 levels, respectively.

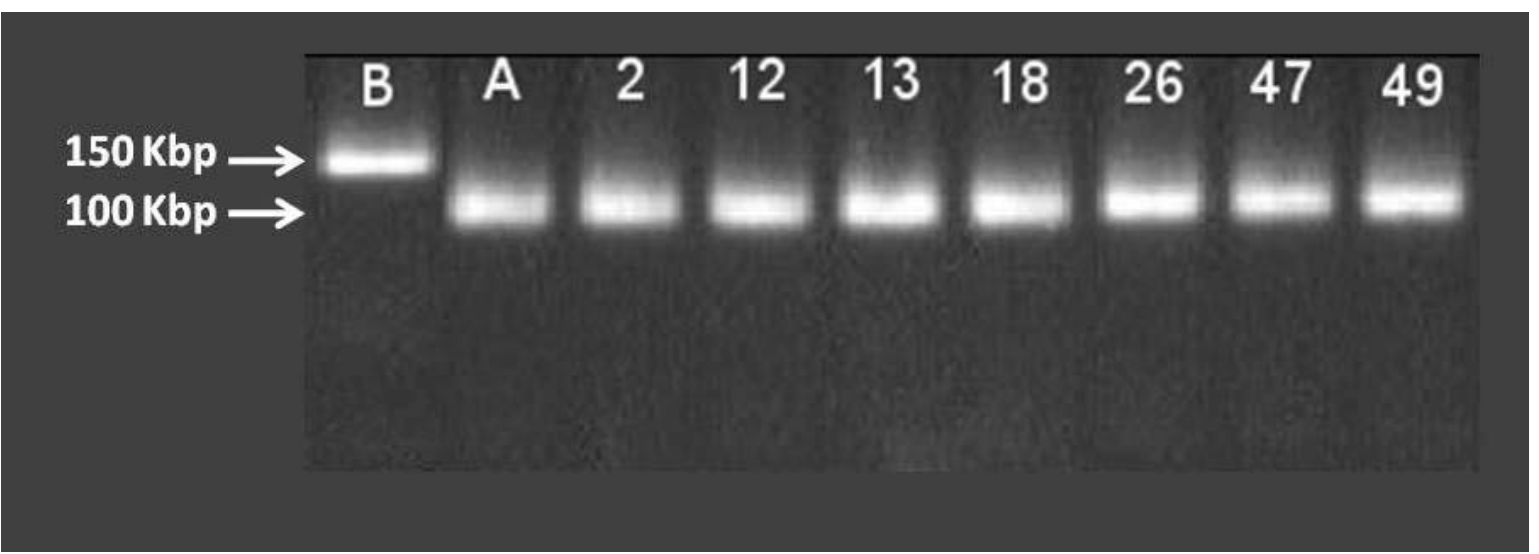

Fig 1. Purity PCR analysis using drrcms marker of IR 70368B, IR 70368A and their derived populations in rice. M, $50 \mathrm{bp}$ DNA ladder, lane A, IR 70368B; lane B, IR 70368A; lanes 3 to 10, selected rice populations of 2, 12, 13, 18, 26, 47, 49 , respectively. 
In a study by Abo Yousef et al (2011) to estimate the genetic purity to CMS line with their maintainer. From 50 hand crosses of IR70368A were planted in 2006 in two experiments (identification and multiplication), only five populations exhibited partial fertility to pollen grains, as well as, seed set in spikelet bagged. These results indicated that the percentage of purity was $90 \%$, and subsequently the genetic purity percentage increased to $96 \%$ in 2007 as shown in (Fig 1), since only two populations exhibited partial fertility to pollen grains. Therefore, the recurrent selection for the CMS line with the hand crosses method is the best method to maintain and increase the genetic purity for IR70368A line. The selection was done on the basis of pollen test and spikelet bagged for the populations which have complete sterility. The results were in agreement with those reported by Zhang et al.(2005).

\section{3- CMS multiplication and produce hybrid seed for $\mathbf{F}_{1}$.}

The success and sustenance of hybrid rice technology largely depends on the availability of high yielding heterotic hybrids with desirable traits and the efficient and economic hybrid seed production, the latter decides the availability of hybrid seed to the farmers at reasonable cost, extensive trials conducted over the years have helped to optimize the seed production package which helps to obtain high seed yields such as synchronization of flowering, row ratio, GA3 application which increase the panicle exsertion for the CMS lines, supplementary pollination, rouging and harvesting to parental lines, the following Table showed the final results to package of recommendation to CMS multiplication and produce the F1 hybrid seed according to Bastawisi et al (2003)

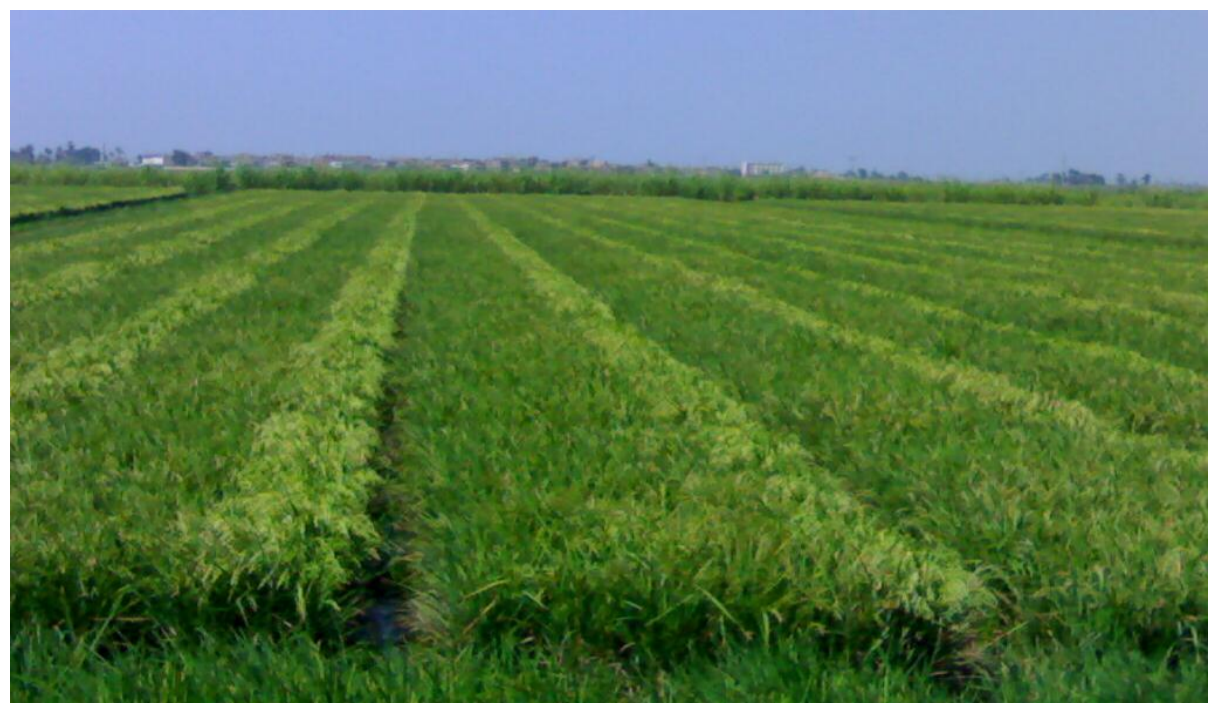

Photo 1. Showed the pattern of transplanting for parental lines to multiplication CMS line for example 2 B line: 8 A line.

Table 3. Optimum package for hybrid rice seed production and CMS multiplication.

\begin{tabular}{|c|c|}
\hline Operation & Particulars \\
\hline Seed rate & $\begin{array}{l}\text { Seed parent : } 25-30 \mathrm{Kg} / \mathrm{ha} \\
\text { Pollen parent : } 8-10 \mathrm{Kg} / \mathrm{ha}\end{array}$ \\
\hline Nursery & Sparse seeding $(20-30 \mathrm{~g} / \mathrm{m} 2)$ to ensure seedlings with $3-5$ tillers in 25 days \\
\hline Row ratio & $\begin{array}{l}8 \text { A line : } 2 \text { B line } \\
8 \text { A line }: 2 \text { B line or } 10 \text { A line }: 2 \text { B line }\end{array}$ \\
\hline Number of seedling / hill & $\begin{array}{l}2-3 \text { for seed parent } \\
2-3 \text { for pollen parent }\end{array}$ \\
\hline Spacing & $\begin{array}{l}\text { Male : male } 20 \mathrm{~cm} \\
\text { Male : female } 25 \mathrm{~cm} \text { and } 30 \mathrm{~cm} \\
\text { Female : female } 15 \mathrm{~cm} \\
\text { Plant : plant } 15 \mathrm{~cm}\end{array}$ \\
\hline $\mathrm{GA}_{3}$ application & $\begin{array}{l}200 \mathrm{~g} / \mathrm{ha} \text { in } 500 \text { liters of water at } 10 \% \text { of heading in two split doses of } 40 \% \\
\text { and } 60 \% \text { in an consecutive days }\end{array}$ \\
\hline Supplementary pollination & 3-4 time a day at peak anthesis time with 30 minutes interval \\
\hline Rouging & $\begin{array}{l}\text { At vegetative phase based on morphological traits } \\
\text { At flowering before anthesis } \\
\text { At maturity based on grain characteristics and seed set rate after removing R line }\end{array}$ \\
\hline Seed yield & $\begin{array}{l}\mathrm{A} \times \mathrm{B}: 2.5-3.0 \mathrm{t} / \mathrm{ha} \\
\mathrm{A} \times \mathrm{R}: 3.0-3.5 \mathrm{t} / \mathrm{ha}\end{array}$ \\
\hline
\end{tabular}




\section{4-Genetic purity testing in F1 hybrid seed a- Got experiment.}

Genetic purity of parental lines and hybrids is of crucial importance, as one percent reduction in purity of hybrid seeds results in a reduction of about 100 $\mathrm{kg} / \mathrm{ha}$ in the yield of a commercial crop, traditional genetic purity is tested by Grow Out Tests (GOT), based on morphological assay Yuan et al (2003).
In a study by Abo Yousef $\boldsymbol{e t}$ al. (2009) to estimate the genetic purity percentage as uniformity to the seeds in the lab. ( Table 4 ). The genetic purity in the some lots were very high, which was ranged from 97.3 $\%$, for lot no. 8 to $99.9 \%$, for lot no. 1, although the differences were not significant. While, for germination percentage the values were ranged between 86.5 for lot no. 8 and 89.9 for lot no. 6 and the differences were significant.

Table 4. Mean performance of the seed lots in the Egyptian hybrid rice No. 1 for some vegetative traits during 2008 season.

\begin{tabular}{|c|c|c|c|c|c|c|}
\hline Lot No. & $\begin{array}{l}\text { Germination } \\
\text { percentage } \\
(\%)\end{array}$ & $\begin{array}{l}\text { Genetic } \\
\text { purity in } \\
\text { the lab. }(\%)\end{array}$ & $\begin{array}{l}\text { Agri. } \\
\text { value } \\
(\%)\end{array}$ & $\begin{array}{l}\text { Heading } \\
\text { period(days) }\end{array}$ & $\begin{array}{l}\text { Genetic purity } \\
\text { in the field } \\
(\%)\end{array}$ & $\begin{array}{l}\text { Plant } \\
\text { height }(\mathrm{cm})\end{array}$ \\
\hline 1 & 88.50 & 99.90 & 85.60 & 9.00 & 98.10 & 97.00 \\
\hline 2 & 87.30 & 99.80 & 88.50 & 10.33 & 97.00 & 95.00 \\
\hline 3 & 88.30 & 99.80 & 88.30 & 9.66 & 97.70 & 96.50 \\
\hline 4 & 87.00 & 99.90 & 88.40 & 11.33 & 96.80 & 95.00 \\
\hline 5 & 87.90 & 98.80 & 89.70 & 10.00 & 97.50 & 96.00 \\
\hline 6 & 89.90 & 99.80 & 88.60 & 8.00 & 98.50 & 99.00 \\
\hline 7 & 87.00 & 98.20 & 86.70 & 12.33 & 96.50 & 94.00 \\
\hline 8 & 86.50 & 97.30 & 86.50 & 13.00 & 96.00 & 92.00 \\
\hline L.S.D. (0.05) & 3.284 & N.S & 3.12 & 0.931 & N.S & 4.98 \\
\hline$(0.01)$ & 3.838 & N.S & 3.731 & 1.27 & N.S & 5.63 \\
\hline
\end{tabular}

N.S. = Not significant.

Moreover, the agricultural value ranged between $85.6 \%$, for lot no. 1 , and $89.7 \%$ for lot no. 5 with significant differences. Planted high purity seeds, showed the shortest heading period (eight days, lot no. 6 ), but, the poorer quality seeds showed the longest heading period ( 13 days, lot no. 8 ), indicating that the population with high uniformity showed the shorter period ( eight days ) to complete heading. These data coincided with the genetic purity percentage under field conditions in grow out test experiment, where, the number of off-type plants increased with the poor quality seed lots during 2008 summer season.

Furthermore, significant differences were found among the lots for the number of panicles per plant and its values differed from 19.00 , in lot no. 6, to 29.00 in lot no. 1 (Table 5). For panicle length, lots no.1,3,4 and 6 recorded the highest mean values, which ranged between 24.00 to $25.00 \mathrm{~cm}$. While, lots no. $2,5,7$ and 8 recorded the lowest mean values for this trait and ranged from 22.00 to $23.00 \mathrm{~cm}$. Besides, regarding panicle weight, lots no.1, 3 and 6 recorded the highest mean values, being 4.90, 4.90 and $5.00 \mathrm{~g}$, respectively. While, lots no. 7 and 8 recorded the lowest mean values ( 3.90 and 3.80 grams, respectively ). With respect to seed set, the highest mean values were obtained from lots no, 1 and $6(96.0 \%)$. The lowest mean values were obtained from lot no.8 $(90.70 \%)$. For 100- grain weight, as shown in Table (5), there were significant differences among the lots. The highest value was that of lot no. 8 ( $2.45 \mathrm{~g})$, whereas, the lowest value was that of lot no. $1(2.20 \mathrm{~g})$. The data in Table ( 5 ) further showed that the highest value for the number of panicles/plant was 29.00, but, the lowest value was 19.00 . For the panicle characters, the desirable mean values were 25.50, 5.50 and $96.00 \%$ for lot no. 6 for panicle length, panicle weight and seed set percentage, respectively. Moreover, lot. no. 6, with high genetic purity percentage in the field, gave the highest values of grain yield (14.25 t/ha.) and harvest index percentage $(59.50 \%)$. On the other hand, lot no. 8 , with poor genetic purity percentage, recorded the lowest values of grain yield (9.47 t/ ha) and harvest index $(42.90 \%)$. These results suggested that the genetic purity and germination percentages under lab. Testing could be used as indicators to seedling vigor in early growth stages. However, for determining the heterosis in hybrid grain yield, the grow out test experiment, under the field condition, might be used, and this might need one year before planting. But, using PCR technique, based on the use of specific marker for the parental lines and $F_{1}$ hybrid, it could take shorter time (several weeks).

These results were similar to those obtained by Ingale and Waghmod (2005) who reported that the maximum yield potential was obtained from using 100 $\%$ pure seeds of the parental lines. Also, Yamauchi (1994) showed that the major limitations to the large scale adoption of hybrid in grain rice technology in the tropics were the inadequate level of standard heterosis of grain yield. 
Table 5. Mean performance of the seed lots in the Egyptian hybrid rice No. 1 for grain yield and its components during 2008 season.

\begin{tabular}{cccccccc}
\hline $\begin{array}{c}\text { Lot } \\
(\text { no. })\end{array}$ & $\begin{array}{c}\text { No. of } \\
\text { panicles / } \\
\text { plant }\end{array}$ & $\begin{array}{c}\text { Panicle } \\
\text { length } \\
(\mathrm{cm})\end{array}$ & $\begin{array}{c}\text { Panicle } \\
\text { weight } \\
(\mathrm{gm})\end{array}$ & $\begin{array}{c}\text { Seed set } \\
(\%)\end{array}$ & $\begin{array}{c}\text { 100-grain } \\
\text { weight(gm) }\end{array}$ & $\begin{array}{c}\text { Grain } \\
\text { yield / } \\
(\mathrm{t} / \mathrm{ha})\end{array}$ & $\begin{array}{c}\text { Harvest } \\
\text { index }(\%)\end{array}$ \\
\hline 1 & 29.00 & 24.00 & 4.90 & 96.00 & 2.20 & 13.75 & 58.00 \\
\hline 2 & 21.00 & 23.20 & 4.10 & 93.00 & 2.35 & 11.00 & 52.00 \\
\hline 3 & 25.00 & 24.00 & 4.90 & 95.00 & 2.40 & 13.00 & 56.50 \\
\hline 4 & 27.00 & 24.00 & 4.00 & 92.00 & 2.38 & 9.55 & 48.00 \\
\hline 5 & 29.00 & 23.50 & 4.40 & 94.30 & 2.30 & 11.20 & 55.00 \\
\hline 6 & 21.00 & 25.50 & 5.50 & 96.00 & 2.30 & 14.25 & 59.50 \\
\hline 7 & 20.00 & 23.00 & 3.90 & 91.00 & 2.40 & 9.65 & 46.50 \\
\hline 8 & 19.00 & 22.00 & 3.80 & 90.70 & 2.45 & 9.47 & 42.90 \\
\hline L.S.D. & 1.53 & 1.31 & 0.23 & 4.53 & 0.17 & 0.85 & 1.98 \\
$(0.05)$ & 1.93 & 1.53 & 0.27 & 4.93 & 0.32 & 1.16 & 2.35 \\
\hline
\end{tabular}

\section{b: Molecular technique.}

Detection of genetic purity for the hybrid seeds, which produced from the hybrid combination, IR69625A/G178R, on a large scale, with open pollination by using molecular marker, was an attempt to detect the offtype plants in hybrid seeds, based on molecular level. The RM 212 primer was used for DNA amplification to determine the genetic purity in three lots, which were randomly selected out of the eight lots. Moreover, five gels. of each lot were made and each gel contained ten individual seeds. The results showed that lot No. 6 showed the highest similarity value of genetic purity $99 \%$, compared with lot No. 5, which gave the lowest similarity value $(90.8 \%)$. While, lot No. 4 recorded $98 \%$ similarity value, on the basic number of bands of individual plants, where, the hybrid seeds contained two bands, but, the off-type seeds contained only one band, as shown in Figs. 2 and 3. These results indicated that the genetic purity of hybrid seeds could differ from place to another under a large scale open pollination, depending on the synchronization of flowering for parental lines and the seed purity of the female line (CMS).

\begin{tabular}{|c|c|c|c|c|c|}
\hline Lot & No. of samples & $\begin{array}{c}\text { No. of pure } \\
\text { lines }\end{array}$ & $\begin{array}{c}\text { Purity } \\
(\%)\end{array}$ & Off -type & $\begin{array}{c}\text { Impurity } \\
(\%)\end{array}$ \\
\hline 4 & 50 & 49 & 98 & 1 & 2 \\
\hline
\end{tabular}

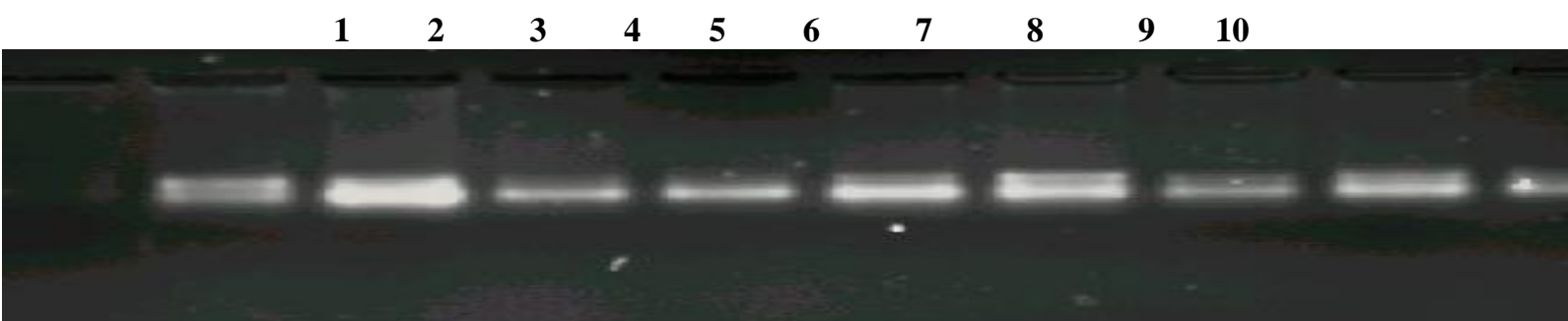

Fig. 3. The hybrid seed purity in lot no.6. Samples no. 2, 3, 4,5, 6, 7, 8, 9 and 10 were hybrid seeds, only no.1 off -type

\begin{tabular}{|c|c|c|c|c|c|}
\hline Lot & No. of samples & $\begin{array}{c}\text { No. of pure } \\
\text { lines }\end{array}$ & $\begin{array}{c}\text { Purity } \\
(\%)\end{array}$ & Off -type & $\begin{array}{c}\text { Impurity } \\
(\%)\end{array}$ \\
\hline 6 & 50 & 50 & 99 & - & 1 \\
\hline
\end{tabular}

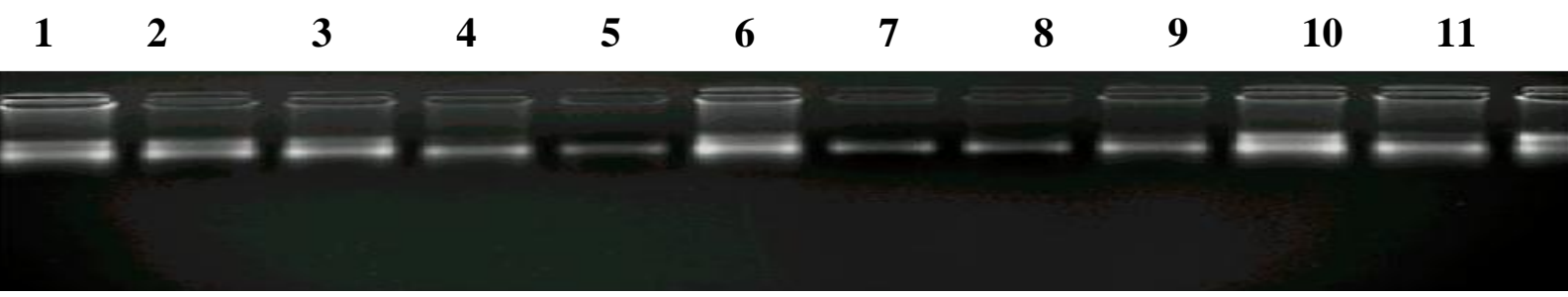

Fig. 4. The hybrid seed purity in lot no.4. Samples no. 1, 2, 3, 4, 5, 6, 7, 8, 9, 10, 11 and 12 were hybrid seeds, without off -type seeds. 
Second -Two line system and One line system: Two line system. For hybrid rice seed production Step $1 \mathrm{~S}$-line $\quad$ Multiplication of female (EGMS) line in a fertility - inducing Environmen

Step $2 \mathrm{~S}$ - line x pollen parent Production of hybrid seed in a Sterility inducing environment

F1 Hybrid seed for commercial cultivation

The discovery and successful utilization of environmental genic male sterility (EGMS) led to develop new promising hybrids of two lines system in hybrid rice breeding program. Compared with the three-line system, the two line system has many advantages for hybrid rice production such as no need to use maintainer line for seed parent multiplication, thus making seed production simpler and more costeffective. EGMS trait is governed by major genes could be transferred to any genetic background and no need to use restorer genes in the male parents of two line hybrids. Finally, this system is ideal for developing indica / japonica hybrids because most japonica lines do not possess restorer genes Virmani et al. (2003).

The EGMS is composed of two major types, photo-sensitive genic male sterility (PGMS), which is responsive to variations in day length, and thermosensitive genic male sterility (TGMS), which is caused by temperature. One such thermo sensitive genic male sterile TGMS line, J207S, is completely sterile when the temperature is lower than $31^{\circ} \mathrm{C}$, but fertile when the temperature is higher than $31^{\circ} \mathrm{C}$, and thus it is named as the reverse-thermo sensitive genic male sterile (rTGMS) line Jia et al. (2001).

In a study by Dora et al (2016), to develop new Japonica hybrids, the mean performance values and standard error for the parents and two japonica hybrid combinations as F3 and F4 generations during 2013 and 2014 seasons under investigation for studied traits are presented in Table 7.

The mean performance values for P1 [M.J. 5460 S] as female line and the other two parents [Sakha106 and GZ.7768] as male lines, showed differences among the three parents for all studied traits. The F4 population's means were 97.12 and 97.89 in cross I and cross II respectively which were lower than the means of $\mathrm{F}_{3}$ population's means 91.33 and 91.23 in cross I and II respectively for days to heading trait. On the other hand, the F4 population's means were higher than the means of $\mathrm{F}_{3}$ populations in the two crosses for no. of tiller plant-1, flag leaf area $(\mathrm{cm} 2)$, seed set $\%$ and yield plant-1 which indicated the improvement for most studied traits under selection. Especially the improvement in yield plant-1 trait for the F4 population's means were 66.46 and 70.09 in the cross I and cross II respectively which were higher than the F3 population's means which were 63.56 and 65.91 in the cross I and cross II respectively.

Molecular studies is concerned on selecting populations which can be used as the new reversethermo sensitive genic male sterile (rTGMS) lines to produce Japonica hybrids under Egyptian condition by using one specific SSR primer RM222 according to Jia et al. (2001).

Our goals in this investigation were summarized in selecting emphasized on high of yielding populations with improved desirable traits. Molecular studies were used to support field experiments to select the best populations which could be used as female (rTGMS) and male lines to use it to produce high productivity Japonica hybrid rice under Egyptian conditions. Data presented in Fig. 3 demonstrated that the application of RM222 as SSR primer revealed the presence of only one DNA band with molecular size of $200 \mathrm{bp}$. This band was found in the rTGMS line (M.J $5460 \mathrm{~S}$ ) as female line and all used populations, except population no. 2 which did not exhibit this band. Also, this band was completely absent in Sakha 106 line, which used as a male line in this experiment.

It could be concluded that this DNA band (200 bp) plays an important role in the appearance of rTGMS activity in M.J $5460 \mathrm{~S}$ line and the nine lines which produced this band as a result of using specific SSR marker (RM222). Also, this band may be produced as a result of rTGMS gene(s) expression in the M.J 5460 $\mathrm{S}$ line and the nine related populations, which showed this band. From the molecular genetics point of view this band should be isolated, cloned and sequenced in further study to determine its relationship with the gene(s) which are responsible for rTGMS activity. 
Table 7. Mean performance and standard error for the studied traits for two hybrid combinations as $F_{3}$ and $F_{4}$ generations with their parents during 2013 and 2014 seasons.

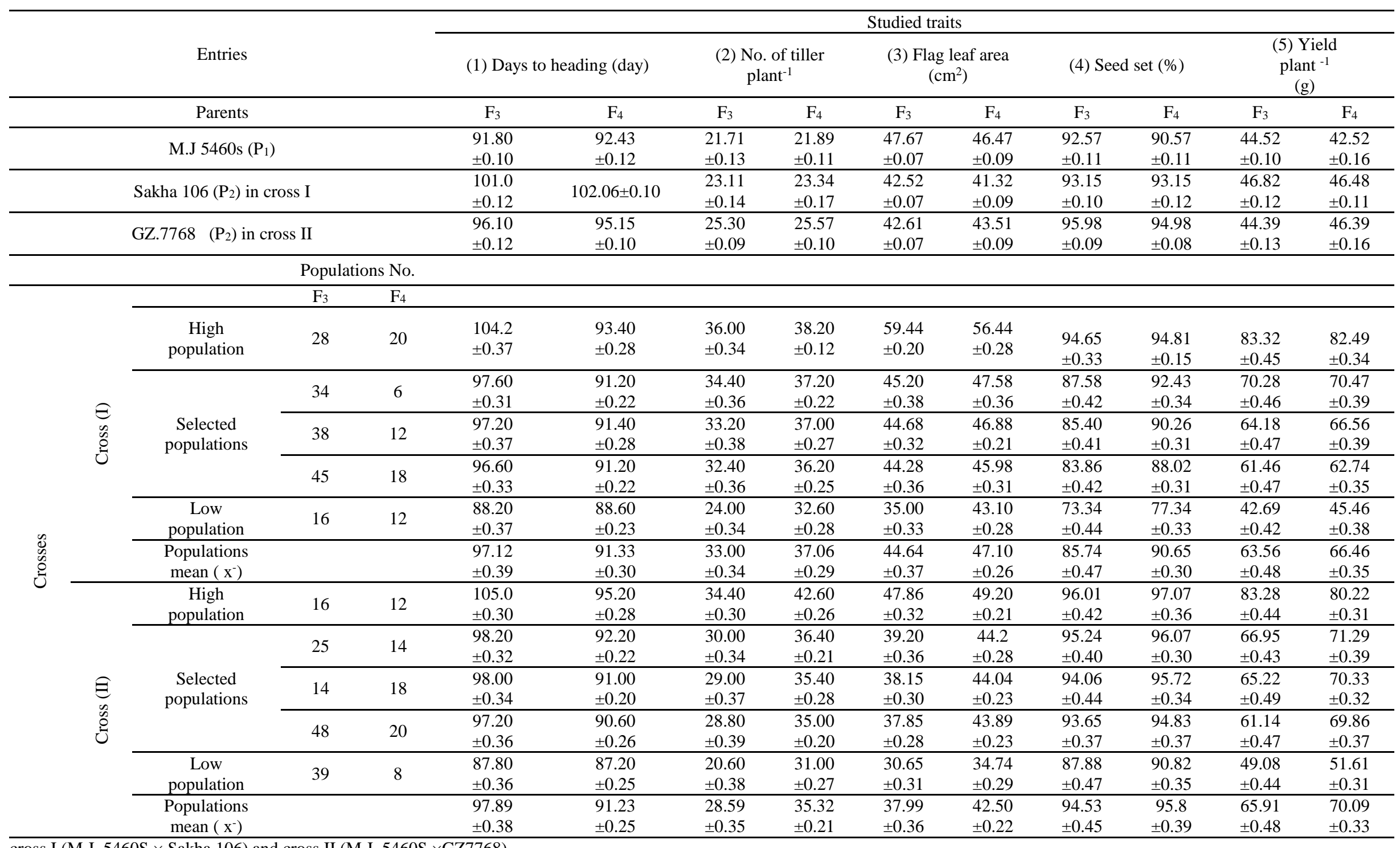




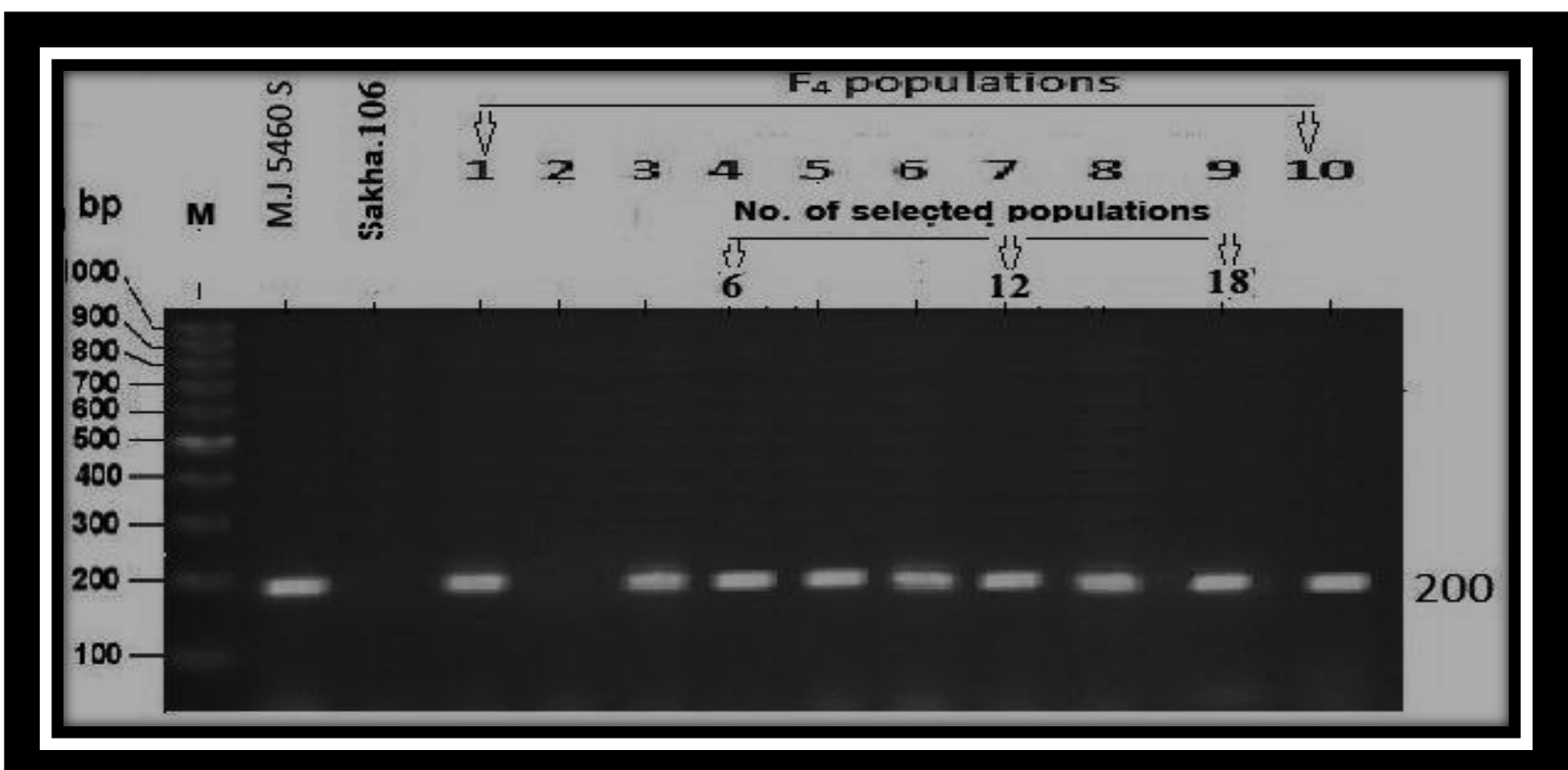

Fig. 5 Agarose gel showing the banding pattern of the tested rice line M.J 5460 S, Sakha 106 and ten selected F4 populations using RM222 marker. $M$ is 100 bp DNA ladder.

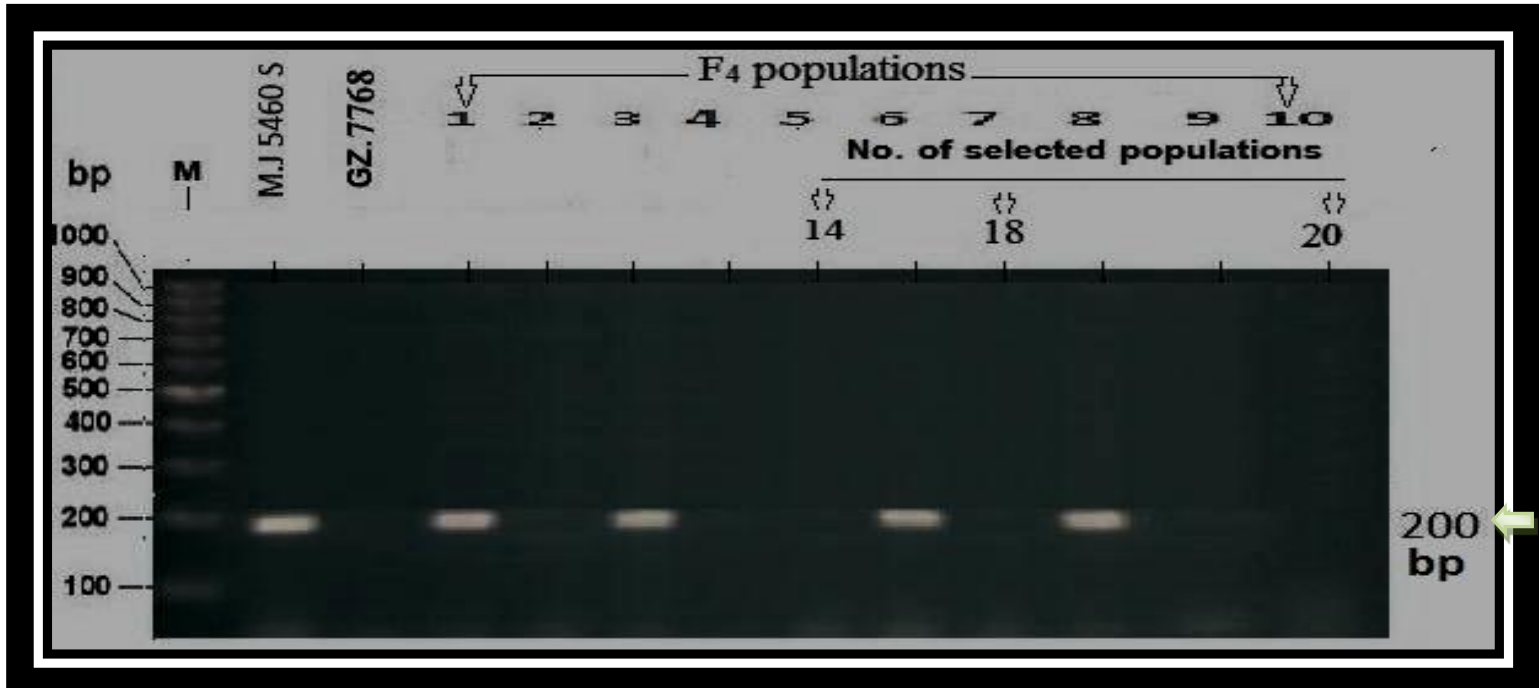

Fig. 6 Agarose gel showing the banding pattern of the tested rice line M.J 5460S, GZ.7768 and ten selected populations of the $\mathrm{F}_{4}$ using RM222 marker. $\mathrm{M}$ is $100 \mathrm{bp}$ DNA ladder.

Data shown in Fig .6) demonstrated that using SSR primer RM222 revealed the presence of the same band (200 bp) found in Fig. 1 with M.J 5460S line as reverse thermo-sensitive genic male sterile line. This band was absent in GZ7768 which was used as a male line in cross II.

This specific band (200 bp) was present in four populations with numbers $1,3,6$ and 8 from ten selected F4 populations and absent in six populations with numbers $2,4,5,7,9$ and 10 which include the best populations selected on the basis of growth and yield traits under field selection experiment with numbers 14, 18 and 20 from twenty F4 populations. On the other hand, the nine populations in Fig.1 and four populations in Fig. 2 which expressed the specific DNA band of $200 \mathrm{bp}$ should be selected and examined for rTGMS activity as a result for the presence of this specific band in their genomes.

This result indicated that analysis of the DNA banding patterns using RM222 marker, revealed a clear difference between the reverse thermo-sensitive genic male sterile (rTGMS) line and the other fertile parents which were used in this study. Similar results were obtained by Jia et al. (2001) who found that, the primer RM222 could be used to identify the rtms1 gene in reverse thermo-sensitive genic male sterile lines, which could be used in japonica hybrid rice seed production.

From these results, it could be concluded that, the mean performance values indicated improvement of most studied traits by selection, high heritability in broad sense (h2b) which indicated that, the genotypic 
variances played the major part of phenotypic variances for most studied traits. The SSR primer RM222 could be used to identify the rtms1 gene (s) of rTGMS lines in japonica hybrid rice seed production program. We recommend that, complete selection should be done in late generations on $\mathrm{F} 4$ population with numbers 6,12 and 18 in cross I for release a new stable rTGMS lines which must be used as female lines and F4 populations with numbers 14, 18 and 20 of cross II which could be used as male lines to produce high yielding Japonica hybrid rice with high productivity under Egyptian conditions.

\section{3- Success of hybrid rice commercialization.}

For high- yielding potential of hybrid rice varieties, hybrid rice was rapidly and widely extended in China and its planting area was steeply to 139000 ha in 1976 from 373 ha in 1975 and 7 ha in 1974. After that, the area under hybrid rice was increasing and increasing with it's per unit area grain yield higher and higher. In 1991, the area of hybrid rice reached 17.6 million ha, accounting for $54 \%$ of total rice area ; the national average grain yield of hybrid rice increased from 4.2 t/ha in 1976, the very beginning of hybrid rice commercialization, to $6.7 \mathrm{t} / \mathrm{ha}$ in 1990 . In recent years, the yearly area under hybrid rice has been about 16 17 million ha, which accounts for $55-60 \%$ of the total rice area, and the production of hybrid rice occupies nearly $60-65 \%$ of the total rice production in China. Up to now.

In Egypt, to develop new promising hybrids under Egyptian conditions and seed production program starting from 2001 and released the first hybrid as commercial variety during 2004 (Bastawisi et al 2005) the following Table (8) showed the total area to produce hybrid seed of hybrid No.1, seed quantity, commercial cultivated area and the productivity ( t/ha.) from 2004 up to now, the fluctuation for these area referred to the promising hybrids were belong to Indica/ Japonica type was which produced from three line system, this type had poor grain quality, but the most Egyptian consumption preferred the Japonica type with good grain quality. So, breeding program tray to develop new promising restorer line with good grain quality for enhancement of the grain quality to the commercial hybrids, second one most of the Egyptian rice varieties are long to compared to Japonica type with high yielding, so they could be utilized as male parent with female line ( Environmental male sterile line ) to produce hybrid seed of Japonica hybrid under upper Egypt conditions.

Table 8. Cultivated area to produce hybrid seed for commercial hybrid ( Egyptian hybrid No.1, seed quantity, commercial cultivated area and the productivity ( $\mathrm{t} / \mathrm{ha}$.) from 2004 up to now.

\begin{tabular}{|c|c|c|c|c|c|c|}
\hline Season & $\begin{array}{c}\text { Area }(\mathrm{A} / \mathrm{R}) \\
\text { ha. }\end{array}$ & Pro. Ton & Destr. \% & $\begin{array}{c}\text { Cultivated area } \\
\text { ha. }\end{array}$ & Yeild t/ha. & $\begin{array}{c}\% \text { overcheck } \\
\text { Gize } 178\end{array}$ \\
\hline 2004 & 4.2 & 7.6 & - & - & - & \\
\hline 2005 & 12.6 & 15.4 & 100 & 202 & 12.55 & 22.19 \\
\hline 2006 & 50.4 & 25.6 & 100 & 631 & 12.67 & 23.08 \\
\hline 2007 & 50.4 & 42.8 & 100 & 1050 & 11.97 & 17.95 \\
\hline 2008 & 42.0 & 48.2 & 92 & 1765 & 12.44 & 21.99 \\
\hline 2009 & 37.8 & 30.7 & 88 & 2016 & 12.23 & 21.68 \\
\hline 2010 & 18.9 & 20.8 & 92 & 1260 & 12.29 & 21.23 \\
\hline 2011 & 8.4 & 8.64 & 100 & 840 & 11.95 & 18.67 \\
\hline 2012 & 12.6 & 15.7 & 100 & 363 & 12.30 & 22.45 \\
\hline 2013 & 18.9 & 24.6 & 100 & 660 & 12.39 & 22.34 \\
\hline 2014 & 21.0 & 24.7 & 88 & 1034 & 12.48 & 21.18 \\
\hline 2015 & 8.40 & 7.8 & 59.5 & 617 & 11.96 & 20.54 \\
\hline 2016 & 18.9 & 36.6 & 100 & 311 & 12.37 & 21.68 \\
\hline 2017 & 21.0 & - & 67.2 & 1280 & 12.39 & 21.24 \\
\hline
\end{tabular}

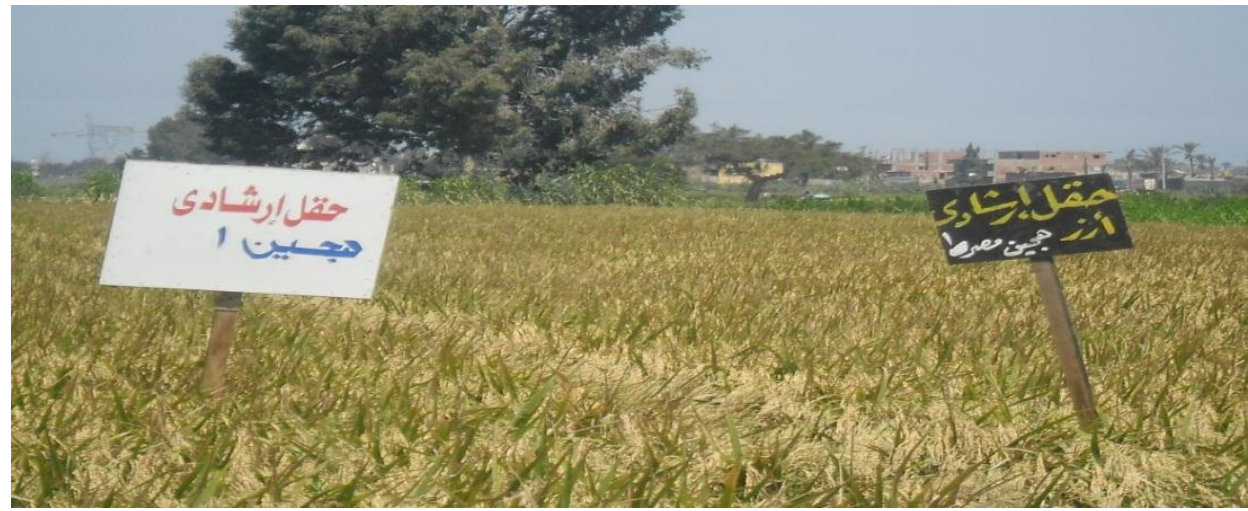

Photo (2) showed the performance of commercial hybrid Egyptian No.1 in the demonstration field. 
An appropriate agronomic package is needed to get high productivity of rice crop to cover the needs of the increasing population. Sowing date, seed rate, seedling age, plant spacing, fertilizer levels and number of seedling per hill are the most important factors, which limit rice yield, poor agronomic management of hybrid rice, low yield of hybrid seed production, high seed cost and poor grain quality, under favorable growing conditions, heterosis for grain yield is usually attributed to higher biomass production, the Package of cultivation practices for hybrid rice under Egyptian conditions were found in the Table (9) .

Table 9. Package of cultivation practices for hybrid rice under Egyptian conditions.

\begin{tabular}{ll}
\hline \multicolumn{1}{c}{ Operation } & \multicolumn{1}{c}{ Particulars } \\
\hline Seed rate & $25-30 \mathrm{~kg} / \mathrm{ha}$ \\
\hline Nursery seeding density & $20-30 \mathrm{~g} / \mathrm{m}$ \\
\hline Spacing & $20 \times 15$ or $20 \times 20 \mathrm{~cm}$ \\
\hline Seedling / hill & $2-3$ \\
\hline Seedling age & 25 days \\
\hline Nitrogen application & $150 \mathrm{~kg} / \mathrm{ha}$ in three splits \\
\hline Phosphorus & $45 \mathrm{~kg} / \mathrm{ha}$ \\
\hline Potach & $60 \mathrm{~kg} / \mathrm{ha}$ \\
\hline Zinc & $30 \mathrm{~kg} / \mathrm{ha}$ \\
\hline Plant protection & Need based \\
\hline
\end{tabular}

\section{4 ) Application for anther cultural technique:}

Tissue culture techniques of rice became a strong fact for rice improvement in all over the world. Anther culture of rice has been feasible for over twenty years. While first developed in Japan Niizeki and Oono (1968), it is used most extensively in China where over a dozen of important varieties have been developed via anther culture. The major advantages of anther culture are reduction in the time required to obtain homozygous lines and increased selection efficiency Chen (1986). Anther culture provides the opportunity to fix recessive genes and to compare the blast behavior of these lines with lines obtained through standard procedures. The highest calls induction rate was recorded with Japonica/ Indica parent and efficiencies were lower in crosses with Indica/Japonica parent, Draz et al, (1991) . Ibrahim et al (1994) found the calls induction and regeneration may be ordered as follows, Japonica $>$ Indica $>$ Japonica/Indica hybrids, moreover, the differences in callusing ability and regeneration efficiency between parent and hybrids may depend on factors such as differences in combining ability of parents. The Japonica hybrids ( produced from japonica/ japonica) possessed high response calls induction and plant regeneration \% compared to Indica and Indica/ Japonica types (Aboyousef 1996) and could develop new promising lines from this technique .

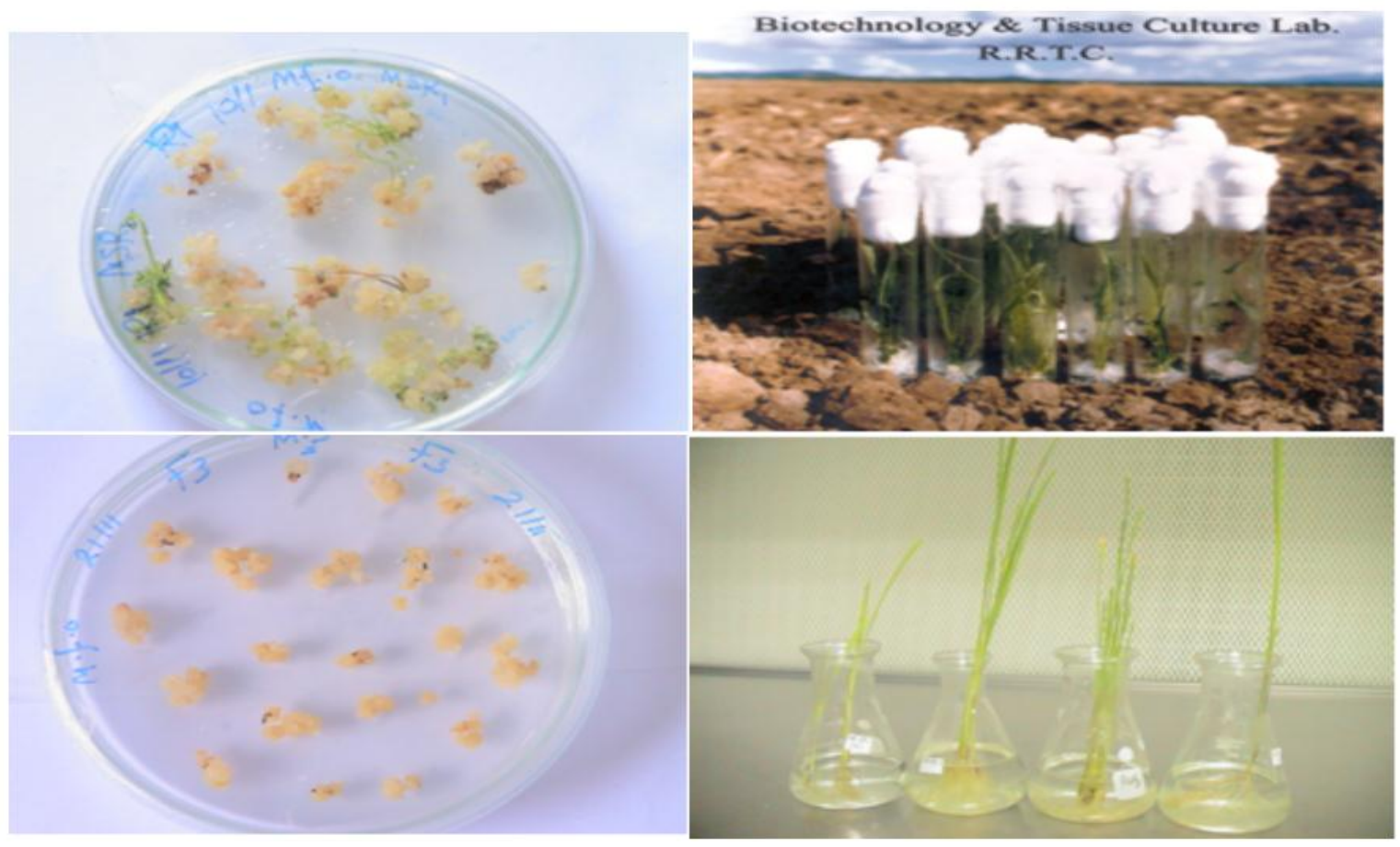

Photo ( 3) Anther culture stages to produce rice promising lines at biotechnology and tissue culture labe. 


\section{References}

Abo- Youssef M.I ; I. A. Talha ; F.A. El Emery and W.H. El - Kallawy (2017). Prediction of combining ability, gene action and heterosis for some botanical and yield characters of rice genotypes ( Oryza sativa L) .11th International Plant Breeding Conference, Kafer El-Sheikh Univ, Egypt .

Abo Youssef, M. I. ; A. A. Abd Allah ; S. M. Shehata and A. F. Abdelkhalik (2009). Using morphological and molecular methods to determine the genetic purity of hybrid seeds of the Egyptian hybrid rice cultivar No.1. J.Agric. Sci. Mansoura Univ.,34(10):9833-9840.

Abo Youssef, M. I.; S. A. Dora; S. F. Deraz, A. A. M. Abo-Shosha, A. A. Khalil, M. A. A. El-Sayed (2011). Estamiting the genetic purity in cytoplasmic male sterile (CMS) lines of Egyptian rice. Austalian Journal of Crop Science. AJCS 5(3): $254-261$.

Abo Youssef, M.I. (1996). Genetic studies on earliness in rice. M.Sc. Genetics. Dep. Faculty of Agric. Zagazig Univeristy.

Ahmadikhah, A. (2010). Study on selection effect, genetic advance and genetic parameters in rice. Annals of Biological Research, 1 (4) : 45-51.

Ahmed, M. I. , M. S. Ramesh and B. C. Viraktamath. ( 2007 ). Hybrid rice in India, DRR , Technical Bulletin No. 26.

Bastawisi, A.O.,H.F.EL-Mowafi, M.I.Abo Youssef, A.E. Draz, I.R. Aidy, S.A.Ghanem, A.A. El-Kady, M.F. Sabaa, M.A.Maximos and A.T.Badawi (2005). .Hybrid Rice Technology in Egypt. Egypt. J. Res., 83(5A): 47-60.

Bastawisi, A.O.; H.F. El-Mowafi; M.I. Abo Youssef; A.E. Draz; I.R. Aidy; M.A. Maximos and A.T. Badawi (2003). Hybrid rice research and development in Egypt. 4th Int. Symposium on Hybrid Rice 14-17 May 2002, Hanoi, Vietnam.

Chen, Y. (1986). Anther and pollen culture of rice. In haploids of higher plants in Vitro, springen Verlag, New york, pp3-25.

Devanand , P. S. , M. Rangaswamy and $\mathbf{H}$. Ikehashi. (1999). Identification of hybrid sterility gene loci in two cytoplasmic male sterile lines in rice. Crop Science 40 : (3 ), 640-646.

Dora, S.A.; M. El-Dinary, M. I. Abo Yousef and M. E. Selim (2017). Genetic behavior for reverse Thermo-sensitive Genic Male Sterility (rTGMS) through segregating generations of some rice genotypes in Egypt. J.Agric. Res. Kafer El-Sheikh Univ, A-Plant production.43(1) 26-36.

Draz, A.E; F.J . Zapata and G.S. Khush (1991). Development of dihaploid rice lines through anther culture. International Rice Research Nots. 16.5.

Duvick, D. N. (1999). Heterosis: Feeding people and protecting natural resources. In: Genetics and
Exploitation of Heterosis in Crops. American Society of Agronomy, Inc., Crop Science Society of America, Inc., Soil Science Society of America, Inc. Madison, Wisconsin, USA.

El-Mowafi, H.F.; A.O. Bastawisi; M.I. Abo Youssef and F.U. Zaman (2005). Exploitation of rice heterosis under Egyptian conditions. 10th Nat. Conf. Agron., 7-10 Oct., 2003. Suez Canal Univ. Fac. of Env. Agric. Sci., El-Arish .

Ibrahim, SM; SA Han; X Lei; PM Colowit and DJ Mackill (1994). Improvement in anther culture of Japonica/Indica crosses of rice. International Rice Research Nots. 19.3.

Ingale, B. V. and B. D. Waghmode. ( 2005 ). Evaluation of newly developed CMS lines of rice (Oryza sativa L.) for their agronomical and floral traits. Indian Journal of Genetics. 64(4):286-290.

Jayashudha, S. and D. Sharma (2010). Identification of maintainers and restorers for CMS lines of rice under shallow low lands. Electronic Journal of Plant Breeding, 1: 311-314.

Jia, J. H; D. S. Zhang; C. Y. Li; X. P. Qu and S. W. Wang (2001). Molecular mapping of the reverse thermo-sensitive genic male-sterile gene (rtms1) in rice. Theor Appl Genet 103:607-612.

Jiming P. and Y. Long Peng. ( 2007 ). Methodology for genetic purification of hybrid rice parents. China Science and Technology press.

Maximos, M.A. and I.R. Aidy (1994). Hybrid rice research in Egypt. In: Virmani, S.S. editor. Hybrid rice technology: New development and future prospects. Manila (Philippines), International Rice Research Institute. P. 227-233.

Niizeki, H and K Oono (1968) Induction of haploid rice plants from anthers culture. Proc. Jpn. Acad, 44: 554-557.

Nuruzzaman, M. M., F. Alam, M. G. Ahmed, M. A. Sohael, M. K. Biswas, M. R. Amin and M. M. Hossain (2002). Studies on parental variability and heterosis in rice (Oryza sativa L.). Pak. J.Biol. Sci. Biol. Sci., 5(10): 1006-1009.

Virmani, S. S.; Sun, Z. X.; T. M. Mou; A. A. Juhar and C. X. Mao (2003). Tow line hybrid rice breeding manual, p 15-22. IRRI, Manila, Philippines.

Yuan L. p., W. Xiaojin, L. Fuming, M. Guohui and $X$. Aiusheng. (2003). Hybrid Rice Technology. China Agriculture Press, Beijing, China.

Yuan, L. P. and S. S. Virmani (1994). Status of hybrid rice research and development. In: Hybrid Rice, p. 7-24. IRRI, Manila, Philippines.

Zhang L.H.; L.Y. Wang; L. Zhang; J.J. Wang (2005). Breeding of large-panicle and earlymaturing indica CMS (cytoplasmic male sterile) line Zhe 94: Hybrid-Rice. 20:6, 7-8. 
